\section{Protest movement in Japan}

\section{Tokyo}

CHINEsE students in Japan have formed an underground movement to keep alive the spirit of the pro-democracy demonstrations crushed in Beijing's Tiananmen Square massacre on 4 June. The Tokyobased movement represents the first concerted effort by Chinese students in Japan to form an active organized resistance to Beijing's crackdown against antigovernment activists.

Japan, with nearly 30,000 students from the People's Republic of China, is the second largest base for Chinese foreign students after the United States. Chinese students in Japan have in the past played an influential role in shaping Chinese politics. A classic example is Lu Xun, who as a medical student in Japan before the Second World War wrote several books on the shortcomings of China, the most famous of which is The True Story of Ah $Q$. His writings had a great influence on reformists before the communist revolution of 1949 and were adopted as communist teachings by Mao Tse Tung in the 1950s.

The identities of participants in the new underground movement have been kept largely secret, but this month the first signs of it emerged in Tokyo. A group calling itself "Chinese students' association for furthering democracy" published the first edition of Democratic China, a magazine calling for more democracy, freedom and the overthrow of China's current leadership.

The 72-page magazine carries gruesome black-and-white pictures of the carnage on the streets of Beijing in early June, editorials lambasting Beijing's leaders as "butchers" and articles detailing resistance movements of other overseas Chinese students, mainly in the United States. It is not clear how many Chinese students are involved in writing and publishing the magazine but Japanese sources close to the underground movement said it had at least 20 active members. About 3,000 copies of the magazine have been sold at bookstores in Japan that deal with Chinese literature. A Japanese source said one of the current leaders of the movement is Yang Zhongmei, a student whose name appears alone on the front pages of Democratic China.

Beijing has branded all pro-democracy student activists "counter-revolutionaries" and has mounted nationwide manhunts within China to arrest them. Chinese students in Japan say that speaking out against the government could limit their chances of being allowed to stay abroad, cause persecution of their families and bring them punishment on their return.

"China is far too unstable at the moment. It is impossible to tell what the government will do next", said one self- paying Chinese student from Shanghai who had nothing to do with the underground movement. "Chinese secret police are very active in Japan. There have been some new, suspicious students at our school. The best thing to do is not talk to Chinese here about politics." China's embassy in Tokyo maintains that conditions for Chinese students in Japan have not changed. An official in the overseas study department of the embassy says there have been no cases so far of "counterrevolutionary" students being sent back to

\section{Washington}

RUMOURS of spying and surveillance by agents of the Chinese government are rife among Chinese students and academics in the United States. At a rally on Capitol Hill last week organized by a newly formed pro-democracy group, the National Coordination Committee on Chinese Student Affairs, students said that many had received warning telephone calls and even death threats from unidentified callers who they suspect to be Chinese embassy staff or government agents. Gong Xiaoxia, a graduate student at Harvard University and one of the organizers of a pro-democracy group, the China Information Center, based near Boston, says the centre is being watched. The office has been broken into and students have received telephone calls warning them that they are doing "very dangerous things".

The Chinese Embassy in Washington denies any involvement, saying in an official memorandum that "it is our consistent position to oppose any kind of monitoring, harassing or intimidating of overseas Chinese students, directly or indirectly". But neither US congressmen nor students give much credence to the words of embassy staff.

The Chinese government has stopped making daily announcements of arrests and sentencings but has not stopped rounding up "counter-revolutionaries". Last week it issued a new list of 48 most wanted people. Among those arrested last week was Yang Wei, a former graduate student in biochemistry at the University of Arizona, who had been released from prison in January after serving a two-year sentence for pro-democracy activities. Congress passed a resolution calling for his release in 1987 when he became the first Chinese studying in the United States to be arrested for political activities. The human rights group Asia Watch also reported this week the arrests of Liu Fang, a student at Beijing Medical University,
China. But the official said the number of self-paying students arriving from China has drastically decreased since 20 June when Beijing imposed stringent new restrictions on overseas travel.

The new regulations in Beijing require people going abroad to obtain "positive vetting" from their supervisor, university, school or work unit certifying that they did not take part in "counter-revolutionary" activities. The restriction has made many people wary of applying to leave the country, "but it is mainly a bureaucratic problem which should ease over the next few months", the Chinese official said.

David Swinbanks

\title{
... and in the United States
}

and Zhou Duo, an economist with Stone Corporation, China's largest computer company.

Various bills introduced to allow Chinese students and academics to extend their stays in the United States were examined last week by the House of Representatives subcommittee on immigration, refugees and international law. The most strongly supported bill, with more than 240 sponsors, is similar to that passed unanimously by the Senate last week (see Nature 340, 174; 20 July 1989) and would waive the $\mathrm{J}-1$ visa requirement that students return to China for at least two years when their studies are completed. A bill sponsored by the committee's chairman Bruce Morrison (Democrat, Connecticut) would create a new legal status called "temporary protected status" which could apply to threatened people of any nationality. Both bills were approved by the subcommittee but are unlikely to be voted on before the summer recess in two weeks time.

The committee did not approve a bill which would make it easier for Chinese to get political asylum and another which would allow an increase in the number of immigrants from Hong Kong.

Congressmen also attacked the oneyear visa extension granted to Chinese students by President George Bush immediately after the Tiananmen Square killings. Only four students have taken up the president's offer because it requires a formal application that may mark people for punishment when they eventually go home. But Paul Virtue, acting general counsel of the Immigration and Naturalisation Service, said the administration opposed further measures and that the current one-year visa extension was a success. He argued that a waiver of the twoyear residency requirement would benefit those who opposed democratic reforms as well as those who supported them, and it could jeopardize future exchange programmes. 